\title{
Dissociation of Analgesic and Hormonal Responses to Forced Swim Stress Using Opioid Receptor Knockout Mice
}

\author{
Candice Contet', Claire Gavériaux-Ruff', Audrey Matifas', Claudia Caradec ${ }^{2}$, Marie-France Champy ${ }^{2}$ \\ and Brigitte $\mathbf{L}$ Kieffer*, I \\ 'Institut de Génétique et de Biologie Moléculaire et Cellulaire, CNRS/INSERM/ULP, IIIkirch, France; ${ }^{2}$ Institut Clinique de la Souris, \\ Génopole de Strasbourg, IIIkirch, France
}

\begin{abstract}
Exposure to stress triggers hormonal and behavioral responses. It has been shown that the endogenous opioid system plays a role in some physiological reactions to stress. The opioid system was described to mediate analgesia induced by mild stressors and to modulate the activation of the hypothalamic-pituitary-adrenal axis. Our study assessed the contribution of opioid receptors in stress-induced analgesia and adrenocorticotropic hormone (ACTH) and corticosterone release by a genetic approach. We performed a parallel analysis of mice deficient in mu, delta, or kappa opioid receptors, as well as of triple opioid receptor knockout mice, following exposure to a mild stress (3-min swim at $32^{\circ} \mathrm{C}$ ). In wild-type mice, stress elicited an increase in jumping latency on the hot plate, which was influenced by gender and genetic background. This analgesic response was reversed both by naloxone and by the triple mutation, and decreased in mu and delta opioid receptor knockout females. In wild-type females, stress also delayed front- and hindpaw behaviors in the hot plate test and increased tail-flick latency in the tail immersion test. Opioid receptor deletion however did not affect these stress responses. In addition, stress produced an increase in ACTH and corticosterone plasma levels. This endocrine response remained unchanged in all mutant strains. Therefore our data indicate that, under our stress conditions, the endogenous opioid system is recruited to produce some analgesia whereas it does not influence hypothalamic-pituitary-adrenal axis activity. This implies that brain circuits mediating analgesic and hormonal responses to stress can be dissociated.

Neuropsychopharmacology (2006) 3 I, I733- 1744. doi: I0.1038/sj.npp. I 300934; published online 12 October 2005
\end{abstract}

Keywords: stress; opioid receptors; knockout; analgesia; ACTH; corticosterone

\section{INTRODUCTION}

Exposure to a stressful stimulus is perceived as a threat to the organism's homeostasis and elicits a variety of physiological adaptations, encompassing endocrine, autonomic, and behavioral aspects (Yamada and Nabeshima, 1995; Carrasco and Van de Kar, 2003). Chronic exposure to stress may eventually lead to pathological consequences, such as drug abuse (Kreek and Koob, 1998; Goeders, 2003) or depression (Tafet and Bernardini, 2003).

At the behavioral level, response to stress includes a transient decrease of pain sensitivity (Rodgers and Randall, 1988; Yamada and Nabeshima, 1995). Stress-induced analgesia plays an adaptive role to threat and is a component of the defensive behavioral response (Amit and Galina, 1988). It appeared early that stress-induced analgesia could be mediated by at least two distinct

\footnotetext{
*Correspondence: Dr BL Kieffer, Institut de Génétique et de Biologie Moléculaire et Cellulaire, CNRS/INSERM/ULP, Parc d'innovation, I rue Laurent Fries, BP 10I42, 67404 Illkirch Cedex, France, Tel: + 33 388655693, Fax: + 33 388655604, E-mail: briki@igbmc.u-strasbg.fr Received 26 January 2005; revised and accepted 2 September 2005 Online publication: 13 September 2005 at http://www.acnp.org/citations/ Npp09|305050065/default.pdf
}

neuronal mechanisms: opioid (naloxone-reversible) vs non-opioid (naloxone-irreversible). It was demonstrated that the type of stress-induced analgesia was partly determined by the severity of stress (Lewis et al, 1980; Terman et al, 1986; for a review, see Bodnar, 1990). Analgesia induced by a mild stressor, such as a brief swim in lukewarm water, was described as mediated by the endogenous opioid system (Terman et al, 1986; Mogil et al, 1996). Alternatively, non-opioid pain inhibitory pathways are activated by more intense stress and involve neurotransmitter systems such as serotonin (Bodnar et al, 1980; Snow et al, 1982), glutamate (Marek et al, 1992), histamine (Hough et al, 1985; Robertson et al, 1988), and endocannabinoids (Hohmann et al, 2005). Interestingly, a collateral inhibition between opioid and non-opioid mechanisms was demonstrated, with both pathways being mutually antagonistic (Bodnar, 1990).

The use of selective antagonists for each type of opioid receptor has provided insights into the molecular mechanisms underlying opioid-mediated stress-induced analgesia. It appeared that delta as well as mu and kappa systems could be involved, depending on the experimental conditions (for a review, see Yamada and Nabeshima, 1995). More recently, opioid stress-induced analgesia was also 
tested in mice lacking individual components of the endogenous opioid system (for a review, see Kieffer and Gavériaux-Ruff, 2002). Stress-induced analgesia was abolished in prodynorphin knockout mice (McLaughlin et al, 2003), markedly reduced in $\beta$-endorphin knockout mice (Rubinstein et al, 1996; Slugg et al, 2000), and unchanged or promoted in preproenkephalin knockout mice (Konig et al, 1996; Bilkei-Gorzo et al, 2004). One study reported that the late but not the initial phase of opioid stress-induced analgesia was reduced in mu receptor knockout mice (LaBuda et al, 2000). However, neither delta nor kappa receptor knockout mutants were tested yet.

At the hormonal level, the major response to stress involves stimulation of the hypothalamic-pituitary-adrenal (HPA) axis (Miller and O'Callaghan, 2002; Tsigos and Chrousos, 2002). Stress increases the secretion of corticotropin-releasing factor from the paraventricular nucleus of the hypothalamus into the hypophyseal portal system. Corticotropin-releasing factor then triggers the release of adrenocorticotropic hormone $(\mathrm{ACTH})$ from the anterior pituitary gland, which in turn stimulates the secretion of glucocorticoids by the adrenal cortex. The main autonomic response to stress is the activation of the sympathetic nervous system, which causes a massive secretion of catecholamines in the periphery (Carrasco and Van de Kar, 2003; Goldstein, 2003) and induces the mobilization of body's energy required to prepare the 'fight or flight' response to stress (Cannon, 1939).

A role for the endogenous opioid system in the response to stress was also suggested at the endocrine and autonomic levels. First, the regional distribution of opioid peptides and receptors suggests a functional interaction between the opioid system and the HPA axis. Many brain areas involved in the neurobiology of stress, including autonomic nervous system centers, are richly innervated by opioidergic neurons and express opioid receptors. Besides, stress promotes the expression and the release of opioid peptides in these regions (see Przewlocki, 1993; Drolet et al, 2001). Second, pharmacological studies evidenced that activation of opioid receptors could affect various stress-induced hormonal secretions (Pfeiffer and Herz, 1984; Yamauchi et al, 1997). The net effect (stimulatory or inhibitory) of opioid system on HPA axis activity is however controversial (for reviews, see Pfeiffer and Herz, 1984; Bodnar and Klein, 2004). Experiments in genetically modified mice also brought variable results. In mu opioid receptor knockout mice, chronic restraint stress triggered a lower increase in corticosterone than in wild-type mice, consistent with a stimulatory role of the mu opioid system (Wang et al, 2002). On the other hand, $\beta$-endorphin-deficient mice displayed slightly higher corticosterone levels following social conflict stress, suggesting that this peptide would play an inhibitory role (Vaanholt et al, 2003).

To clarify the contribution of each opioid receptor type in stress-induced hormonal and behavioral effects, we compared wild-type mice to mice deficient in each individual opioid receptor, $\mathrm{mu}(\mathrm{MOR}-/-)$, delta $(\mathrm{DOR}-/-)$, and kappa $\left(\mathrm{KOR}-\mathrm{I}_{-}\right)$receptor knockout mice. In addition, we used mice devoid of all three opioid receptors, namely triple knockout mice $(\mathrm{MKD}-/-)$. In the present study, we report a parallel analysis of analgesia, measured in the hot plate and the tail immersion assays, and of plasma ACTH and corticosterone levels in these mice following a 3-min swim in $32^{\circ} \mathrm{C}$ water.

\section{MATERIALS AND METHODS}

\section{Animals}

Mice lacking mu, delta, or kappa opioid receptors (MOR-/ - , DOR $-/-$, and KOR $-/-$ ) were generated by homologous recombination and have been described earlier (Matthes et al, 1996; Simonin et al, 1998; Filliol et al, 2000). Mice were originally obtained on a hybrid 50\% $129 / \mathrm{SvPas} 50 \% \mathrm{C} 57 \mathrm{BL} /$ $6 \mathrm{~J}$ genetic background and were fully backcrossed on the C57BL/6J background (wild-type counterparts of single knockouts are referred as to WT Bl6). Triple knockout mutants (MKD-/-) were produced by interbreeding of single mutant mice and maintained on the original hybrid 50\% 129/SvPas:50\% C57BL/6J genetic background (wildtype counterparts of triple knockouts are referred as to WT $50: 50)$. In mutant mice, there was no obvious alteration of growth and fertility, as well as no major modification among the remaining components of the opioid system (Kieffer and Gavériaux-Ruff, 2002). These mice were also characterized for their acute antinociceptive response (Martin et al, 2003). Mice, aged 16 weeks on average, were housed under standard conditions in a $12 \mathrm{~h}$ dark-light cycle with free access to water and food. At 4 days prior to the experiments, mice were handled and habituated to the experimental room. Mice were always tested between 08:00 and 11:00 to minimize bias due to circadian rhythm of stress hormone release. In all experiments, genotype, and treatment were blinded to the experimenter until data analysis. All experiments were carried out in accordance with the European Communities Council Directive of 24 November 1986.

\section{Chemicals}

Naloxone hydrochloride was purchased from RBI (Natick, MA).

\section{Stress-Induced Analgesia}

Stress-induced analgesia was assessed in the hot plate and in the tail immersion tests following a mild stress, induced by a 3-min forced swim in $32^{\circ} \mathrm{C}$ water. In preliminary kinetic studies (see section Genetic inactivation of opioid receptors: alternative measures of thermal antinociception and Figures $4 a$ and $5 b$ ), three resting times between the end of swim and the beginning of the assay $(1,2$, and $5 \mathrm{~min}$ ) were tested. In subsequent experiments, a 1-min interval for the tail immersion test and a 2-min interval for the hot plate test were used. For the tail immersion test, the mouse was restrained in a soft tissue pocket and the distal half of the tail dipped into a water bath set at $52^{\circ} \mathrm{C}$. Latency for tailflick was measured with a 10-s cutoff time. For the hot plate test, the mouse was placed on a $52^{\circ} \mathrm{C}$ hot plate and latencies for frontpaw licking and for jumping were recorded, with 60- and 240-s cutoff times, respectively. Jump is defined as having the four paws of the mouse off the hot plate. In a second set of experiments, two other parameters were scored: latencies for hindpaw licking and for hindpaw 
shaking, with 120-s cutoff times. For pharmacological reversal experiments, $10 \mathrm{mg} / \mathrm{kg}$ naloxone or saline was injected s.c. $20 \mathrm{~min}$ before stress. The dose of naloxone was chosen according to the literature (Marek et al, 1992; Menendez et al, 1993; Mogil and Belknap, 1997).

\section{Plasma Corticosterone and ACTH Dosage}

Mice were exposed to a 3 -min swim stress in $32^{\circ} \mathrm{C}$ water. They were then allowed to rest for $10 \mathrm{~min}$ before being killed. The 10-min interval between the end of stress and the time of killing was chosen according to previous articles reporting simultaneous dosage of plasma ACTH and corticosterone (Timpl et al, 1998). Mice were decapitated and trunk blood was collected in tubes containing aprotinin-EDTA. The blood was centrifuged at 3000 r.p.m. for $5 \mathrm{~min}$ to obtain plasma from the supernatant. Plasma samples were aliquoted and stored at $-80^{\circ} \mathrm{C}$ until use. ACTH was quantified with a ${ }^{125}$ I-radioimmunoassay kit (MP Biomedicals, Irvine, CA, reference 07-106101) and 25-50 $\mu \mathrm{l}$ plasma samples were used. Corticosterone was measured with a ${ }^{3} \mathrm{H}$-radioimmunoassay kit (MP Biomedicals, Irvine, CA, reference 07-120002) and 2-10 $\mu$ l plasma samples were used.

\section{Statistical Analysis}

Each group contained 6-30 animals (8-10 on average). Data are presented as means \pm SEM. In all analyses, knockout mice were compared to their wild-type counterparts of corresponding genetic background. Therefore, triple knockout mice were compared to WT 50:50 and single knockout mice were compared to WT Bl6. Statistical analysis was performed using one-, two-, or three-way ANOVAs according to the experimental design. When appropriate, consecutive post hoc comparisons, using the Bonferroni test, were carried out. Results of post hoc analyses are presented in graphs, with symbols representing the level of significance of a difference. One symbol corresponds to $p<0.05$, two symbols to $p<0.01$, and three symbols to $p<0.001$.

\section{RESULTS}

\section{Stress-Induced Analgesia}

Stress-induced analgesia in wild-type mice: effect of gender and genetic background. In wild-type animals, swim stress produced analgesia, as evaluated by an increase of the jump latency in the hot plate test (Figure 1a). Not only was the stress effect significant $(\mathrm{F}(1,166)=145.3$; $p<0.001)$, but sex $(\mathrm{F}(1,166)=29.3 ; p<0.001)$ and genetic background $(\mathrm{F}(1,166)=40.7 ; p<0.001)$ effects were also revealed. Interactions of stress with $\operatorname{sex}(\mathrm{F}(1,166)=6.2$; $p=0.014)$ and with genetic background $(\mathrm{F}(1,166)=3.9$; $p=0.05)$ as well as the triple interaction $(\mathrm{F}(1,166)=6.6$; $p<0.001)$ were significant, but there was no interaction between sex and genetic background $(\mathrm{F}(1,166)=1.6$; $p>0.05)$. Subsequent post hoc comparisons indicated a sexual dimorphism in the C57BL/6J strain (WT Bl6), with female mice showing higher pre- and poststress jump latencies than males. This gender difference was not detected in the hybrid 50\% 129/SvPas:50\% C57BL/6J genetic background (WT 50:50) even if the tendency was the same. Accordingly, genders were analyzed separately in the following experiments. Significant differences between the two genetic backgrounds appeared in nonstressed males and females, as well as in stressed males, with WT 50:50 mice displaying higher jump latencies than WT Bl6 animals. As a consequence, knockout animals were always compared to their wild-type counterparts of corresponding backgrounds: WT Bl6 for single knockout mice and WT 50:50 for the triple mutants.

Frontpaw licking latencies in the hot plate test were also measured (Figure 1b). Both stress $(\mathrm{F}(1,165)=12.3$; $p<0.001)$ and sex $(\mathrm{F}(1,165)=7.5 ; p=0.007)$ effects, but no genetic background effect $(\mathrm{F}(1,165)=0.8 ; \quad p>0.05)$, were detected. None of the interactions was significant (stress $\times$ sex: $\quad \mathrm{F}(1,165)=0.7 ; \quad p>0.05 ; \quad$ stress $\times$ genetic background: $\quad \mathrm{F}(1,165)=0.003 ; \quad p>0.05 ; \quad$ sex $\times$ genetic background: $\mathrm{F}(1,165)=0.1 ; p>0.05)$ except the triple interaction $(\mathrm{F}(1,165)=4.2 ; p=0.04)$. Post hoc analyses pointed out that a significant stress effect was present only in WT Bl6 females. Sexual dimorphism was also found in this single group. Consequently, jumping was considered as the most consistent parameter to assess stress-induced analgesia in the hot plate test as it was reliably affected by stress in both genders of our two mouse genetic backgrounds.

Naloxone effect in wild-type mice. Naloxone administration reduced the level of stress-induced analgesia, as measured by jumping latency, in both genders of both $\mathrm{Bl} 6$ and 50:50 genetic backgrounds (Figure 2).

In WT Bl6 animals (Figure 2a), three-way ANOVAs revealed significant main effects of stress $(\mathrm{F}(1,56)=101.0$; $p<0.001)$ and treatment $(\mathrm{F}(1,56)=93.6 ; p<0.001)$ but not of $\operatorname{sex}(\mathrm{F}(1,56)=2.5 ; p>0.05)$. Interactions of stress with treatment $(\mathrm{F}(1,56)=41.7 ; p<0.001)$ and with sex $(\mathrm{F}(1,56)=16.3 ; p<0.001)$ as well as the triple interaction $(\mathrm{F}(1,56)=5.7 ; p<0.02)$ were significant, but there was no interaction between sex and treatment $(\mathrm{F}(1,56)=2.0$; $p>0.05)$. Consecutive post hoc tests revealed that stress produced analgesia in saline-treated males and females, as well as in naloxone-treated females. Naloxone efficiently decreased poststress jump latencies in both genders and also affected basal nociceptive threshold in males. Sexual dimorphism appeared in saline-treated stressed animals, with female displaying more analgesia, as previously shown in noninjected mice (see section Stress-induced analgesia in wild-type mice: effect of gender and genetic background and Figure 1a).

In WT 50:50 animals (Figure 2b), strong main effects of stress $(\mathrm{F}(1,70)=124.8 ; p<0.001)$, treatment $(\mathrm{F}(1,70)=42.6$; $p<0.001)$, and sex $(\mathrm{F}(1,70)=34.2 ; p<0.001)$ were detected. There were interactions of stress with treatment $(\mathrm{F}(1,70)=8.6 ; p=0.005)$ and with $\operatorname{sex}(\mathrm{F}(1,70)=8.8$; $p=0.004)$ but neither interaction between treatment and sex $(\mathrm{F}(1,70)=0.2 ; p>0.05)$ nor the triple interaction $(\mathrm{F}(1,70)=1.2 ; p>0.05)$ were significant. Simple stress effects were revealed in all groups but naloxone significantly attenuated stress-induced increase of jump latencies in both males and females. Naloxone also decreased basal nociceptive thresholds in females. Gender differences were detected in all groups with the exception of the naloxone-treated 

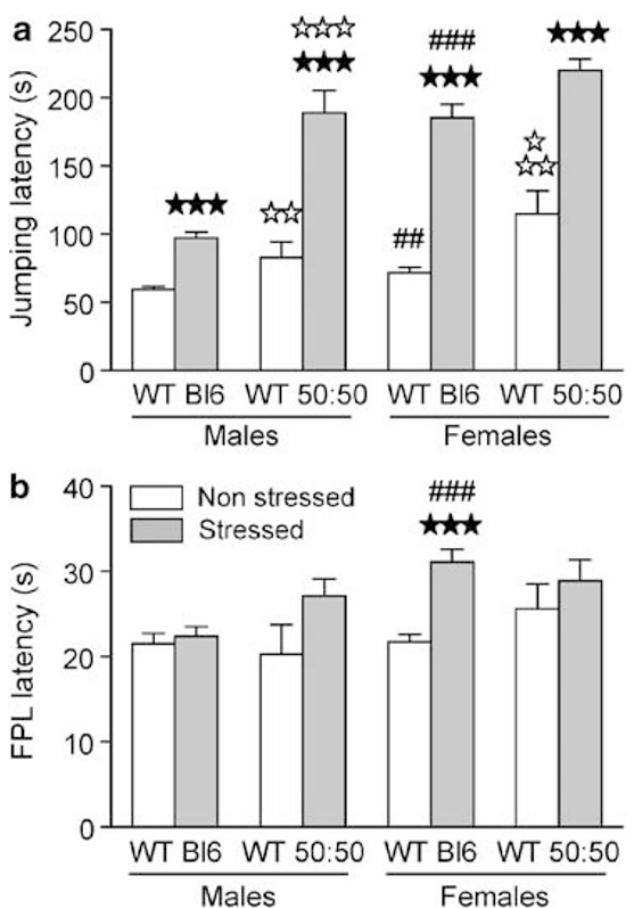

Figure I Sex- and strain-dependent effect of forced swim stress on nociceptive thresholds measured in the hot plate test. Male and female wild-type mice of C57BI/6J (WT Bl6, $n=34-40)$ or C57BI/6) $\times 129 \mathrm{SvPas}$ (WT 50:50, $n=7-9$ ) genetic background were tested. Mice were exposed to forced swim stress during 3 min in $32^{\circ} \mathrm{C}$ water. Antinociception was measured in the hot plate test $2 \mathrm{~min}$ after stress. Latencies for jumping (a) and frontpaw licking (FPL) (b) were recorded. Data are expressed as mean \pm SEM. Data were subjected to three-way ANOVA with stress, genetic background, and sex as between-subject variables. One symbol, $p<0.05$; two symbols, $p<0.0$ I; three symbols, $p<0.00$ I; black stars, effect of stress; white stars, effect of genetic background; sharp symbols, effect of sex (Bonferroni post hoc test).

stressed animals, with females consistently being less sensitive to thermal pain than males.

Genetic inactivation of opioid receptors: jumping latency in the hot plate test. Deletion of all mu, delta, and kappa opioid receptors in triple knockout mice (MKD-I-) led to a decrease in stress-induced analgesia, similar to that obtained after naloxone administration (Figure 3a). Threeway ANOVA revealed stress $(\mathrm{F}(1,53)=91.3 ; p<0.001)$, genotype $(\mathrm{F}(1,53)=161.6 ; p<0.001)$, and sex $(\mathrm{F}(1,53)=$ 7.6; $p=0.008)$ effects. Stress significantly interacted with genotype $(\mathrm{F}(1,53)=21.1 ; p<0.001)$ but interactions of sex with stress $(\mathrm{F}(1,53)=0.7 ; \quad p>0.05)$, with genotype $(\mathrm{F}(1,53)=2.1 ; p>0.05)$, and with stress and genotype $(\mathrm{F}(1,53)=0.8 ; p>0.05)$ were absent. As for naloxone experiment in WT 50:50 mice, simple stress effects were present in all groups and triple mutation significantly decreased poststress jumping latencies, as well as basal nociceptive thresholds. Gender differences did not reach significance.

Deletion of individual opioid receptors in single knockout mice (MOR-I-, DOR $-/-$, and KOR $-/-$ ) indicated a sexdependent role of mu and delta opioid receptors in stressinduced analgesia (Figure $3 \mathrm{~b}-\mathrm{d}$ ). In all single mutants, three-way ANOVAs revealed significant effects of stress $(\mathrm{WT} / \mathrm{MOR}-/-\mathrm{F}(1,193)=145.0 ; p<0.001 ; \mathrm{WT} / \mathrm{DOR}-/-$ :
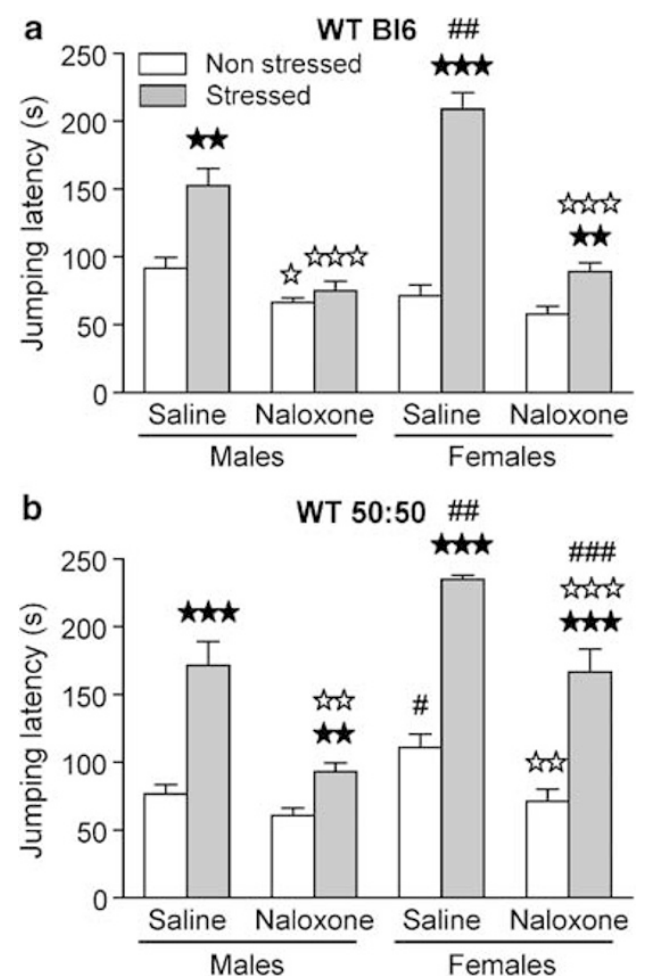

Figure 2 Effect of naloxone on stress-induced analgesia. Male and female wild-type mice of C57BI/6) (WT Bl6 (a)) or C57BI/6) $\times 129 \mathrm{SvPas}$ (WT 50:50 (b)) genetic background were tested $(n=7-1$ I). Antinociception was measured in the hot plate test $2 \mathrm{~min}$ after swim stress. Latencies for jumping were recorded. Saline or $10 \mathrm{mg} / \mathrm{kg}$ naloxone was injected s.c. 20 min before stress. Data are expressed as mean + SEM. Data were subjected to three-way ANOVA with stress, treatment, and sex as between-subject variables. One symbol, $p<0.05$; two symbols, $p<0.0$ l; three symbols, $p<0.00$ I; black stars, effect of stress; white stars, effect of treatment; sharp symbols, effect of sex (Bonferroni post hoc test).

$\mathrm{F}(1,156)=117.9 ; p<0.001 ; \mathrm{WT} / \mathrm{KOR}-/-: \mathrm{F}(1,63)=106.2 ;$ $p<0.001), \quad$ genotype $\quad(\mathrm{WT} / \mathrm{MOR}-/-: \quad \mathrm{F}(1,193)=25.8$; $p<0.001 ; \mathrm{WT} / \mathrm{DOR}-1-: \mathrm{F}(1,156)=7.0 ; p=0.009 ; \mathrm{WT} /$ KOR $-I-: \mathrm{F}(1,63)=5.6 ; p=0.02)$, and sex $(\mathrm{WT} / \mathrm{MOR}-I-$ : $\mathrm{F}(1,193)=46.5 ; p<0.001 ; \quad \mathrm{WT} / \mathrm{DOR}-1-: \mathrm{F}(1,156)=47.1 ;$ $p<0.001 ; \mathrm{WT} / \mathrm{KOR}-1-: \mathrm{F}(1,63)=34.9 ; p<0.001)$. There were major interactions between stress and sex (WT/ MOR-I-: $\quad \mathrm{F}(1,193)=29.4 ; \quad p<0.001 ; \quad$ WT/DOR-I-: $\mathrm{F}(1,156)=18.7 ; \quad p<0.001 ; \quad \mathrm{WT} / \mathrm{KOR}-/-: \quad \mathrm{F}(1,63)=16.8 ;$ $p<0.001)$. Apart from the WT/MOR $-1-$ group $(\mathrm{F}(1,193)=9.6 ; p=0.002)$, there was no interaction between genotype and sex $(\mathrm{WT} / \mathrm{DOR}-/-: \mathrm{F}(1,156)=3.8 ; p>0.05$; $\mathrm{WT} / \mathrm{KOR}-/-: \mathrm{F}(1,63)=1.9 ; p>0.05)$. The pattern was similar for the triple interaction (WT/MOR-/-: $\mathrm{F}(1,193)=3.9 ; \quad p=0.05 ; \quad \mathrm{WT} / \mathrm{DOR}-/-: \quad \mathrm{F}(1,156)=1.1$; $p>0.05 ; \mathrm{WT} / \mathrm{KOR}-1-: \mathrm{F}(1,63)=0.06 ; p>0.05)$. Finally, no interactions between stress and genotype were detected $(\mathrm{WT} / \mathrm{MOR}-1-\mathrm{F}(1,193)=3.4 ; \quad p>0.05 ; \quad \mathrm{WT} / \mathrm{DOR}-1-\mathrm{:}$ $\mathrm{F}(1,156)=0.003 ; \quad p>0.05 ; \quad \mathrm{WT} / \mathrm{KOR}-1-: \quad \mathrm{F}(1,63)=1.5$; $p>0.05)$. Subsequent post hoc analyses revealed that stress strongly increased jump latencies in all groups of animals. Mutation altered basal latencies in MOR $-I-$ males and females, as well as in DOR $-I-$ and KOR $-I-$ female mice. Most importantly, a major genotype effect appeared in stressed MOR-I- females, as well as a slighter one in DOR-/- females, indicating that poststress jumping 

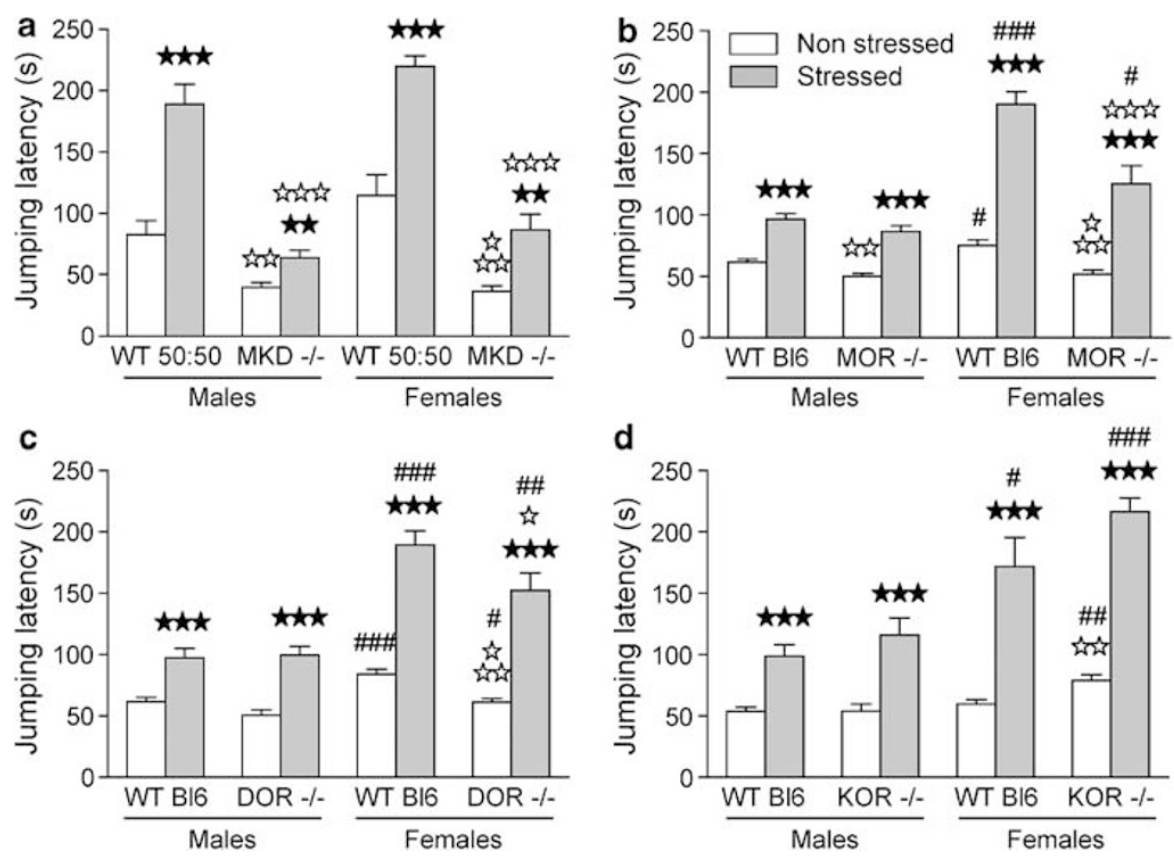

Figure 3 Effect of opioid receptor deletion on stress-induced analgesia. Male and female MKD-l- (a, $n=7-9), M O R-/-(b, n=22-30)$, DOR-I(c, $n=16-26)$, and KOR-1- (d, $n=7-10)$ mice were compared to their wild-type counterparts (WT 50:50 and WT BI6). Antinociception was measured in the hot plate test $2 \mathrm{~min}$ after swim stress. Latencies for jumping were recorded. Data are expressed as mean \pm SEM. Data were subjected to three-way ANOVA with stress, genotype, and sex as between-subject variables. One symbol, $p<0.05$; two symbols, $p<0.01$; three symbols, $p<0.00$ I; black stars, effect of stress; white stars, effect of genotype; sharp symbols, effect of sex (Bonferroni post hoc test).

latencies were significantly reduced in those mice. Sexual dimorphism was detected in most groups of animals, with the exception of MOR-I- nonstressed females.

Genetic inactivation of opioid receptors: alternative measures of thermal antinociception. In order to potentially extend the phenotype of MOR $-I-$ and DOR-Ifemales to other nociceptive measures, WT Bl6 and single knockout females were tested in a distinct thermal pain assay, the tail immersion test. A kinetic study was first performed on WT Bl6 females to assess whether stressinduced analgesia could be detected in this test within 1, 2, or $5 \mathrm{~min}$ after the end of swim stress (Figure $4 \mathrm{a}$ ). One-way ANOVA revealed a main effect of stress $(\mathrm{F}(3,33)=4.8$; $p=0.007)$ and post hoc tests pointed out that stress significantly increased tail-flick latencies 1 and $5 \mathrm{~min}$ after stress. The former time point was selected to test the single knockout females (Figure $4 \mathrm{~b}$ ). In this experiment, there was a significant stress effect $(\mathrm{F}(1,50)=22.1 ; p<0.001)$ but no genotype effect $(\mathrm{F}(3,50)=1.3 ; p>0.05)$ and no interaction between stress and genotype $(\mathrm{F}(3,50)=0.2 ; p>0.05)$. Following post hoc analysis, a stress effect was detected in WT Bl6 and KOR $-I-$ mice but did not reach significance in MOR $-I-$ and DOR $-I-$ animals, although the tendency was clear.

We previously found that stress increased frontpaw licking latencies in WT Bl6 females (see section Stressinduced analgesia in wild-type mice: effect of gender and genetic background and Figure $1 \mathrm{~b}$ ). This parameter was therefore also analyzed in single mutant females (Figure $5 \mathrm{a}$ ). Main effects of stress $(\mathrm{F}(1,169)=76.5 ; p<0.001)$ and genotype $(\mathrm{F}(3,169)=4.5 ; p=0.005)$ were detected but the two variables did not interact with each other $(\mathrm{F}(3,169)=108.1$; $p>0.05)$. A major effect of stress was revealed in all genotypes. Basal frontpaw licking latency was decreased in
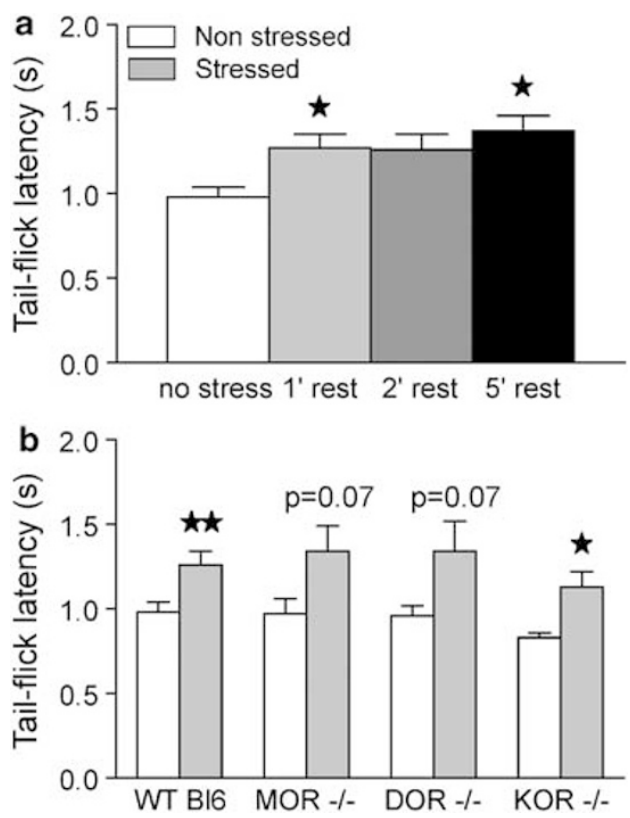

Figure 4 Stress-induced analgesia in wild-type and single knockout females measured in the tail immersion test. (a) Female C57Bl/6J mice were exposed to forced swim stress during $3 \mathrm{~min}$ in $32^{\circ} \mathrm{C}$ water. Antinociception was measured in the tail immersion test I, 2, or 5 min after stress $(n=7-$ 12). Data are expressed as mean \pm SEM. Data were subjected to one-way ANOVA with resting time as between-subject variable. One symbol, $p<0.05$; black star, effect of stress (Bonferroni post hoc test). (b) Female MOR-/-, DOR-1-, and KOR-/- mice were compared to their wildtype counterparts (WT B|6) $(n=6-12)$. Antinociception was measured in the tail immersion test I min after swim stress. Data are expressed as mean \pm SEM. Data were subjected to two-way ANOVA with stress and genotype as between-subject variables. One symbol, $p<0.05$; two symbols, $p<0.0$ l; black stars and ' $p=0.07$ ', effect of stress (Bonferroni post hoc test). 
DOR - / - females, as previously shown for jumping latency (see section Genetic inactivation of opioid receptors: jumping latency in the hot plate test and Figure $3 \mathrm{c}$ ). However, genotype did not alter poststress latencies.

In an independent experiment, the hot plate test was again used with single knockout females and their WT Bl6 counterparts, but other nociceptive responses were evalu-
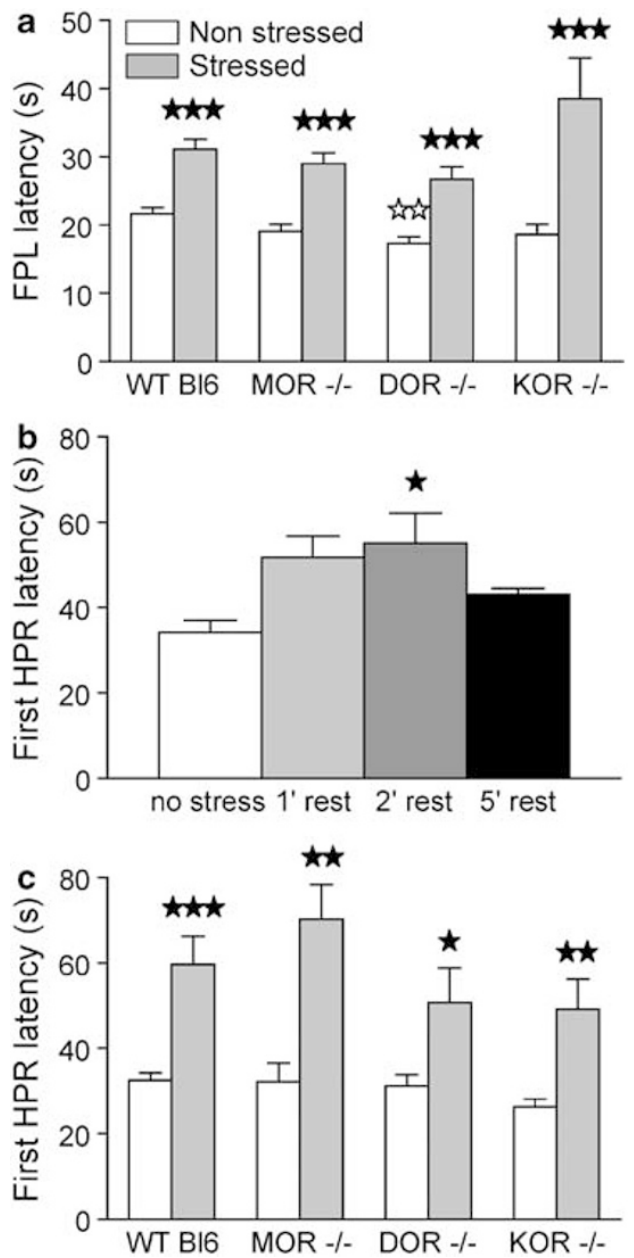

Figure 5 Stress-induced analgesia in wild-type and single knockout females measured by licking latencies in the hot plate test. (a) Female MOR-1-, DOR-1-, and KOR-1- mice were compared to their wildtype counterparts (WT BI6) $(n=7-40)$. Antinociception was measured in the hot plate test 2 min after swim stress. Frontpaw licking (FPL) latencies were recorded. Data are expressed as mean \pm SEM. Data were subjected to two-way ANOVA with stress and genotype as between-subject variables. Two symbols, $p<0.01$; three symbols, $p<0.001$; black stars, effect of stress; white stars, effect of genotype (Bonferroni post hoc test). (b) Female C57BI/6J mice were exposed to forced swim stress during $3 \mathrm{~min}$ in $32^{\circ} \mathrm{C}$ water. Antinociception was measured in the hot plate test 1, 2, or 5 min after stress $(n=8-9)$. First hindpaw response (HPR) latencies were recorded. Data are expressed as mean \pm SEM. Data were subjected to one-way ANOVA with resting time as between-subject variable. One symbol, $p<0.05$; black star, effect of stress (Bonferroni post hoc test). (c) Female MOR-1-, DOR-1-, and KOR-1- mice were compared to their wild-type counterparts (WT Bl6) $(n=6-\mid 4)$. Antinociception was measured in the hot plate test 2 min after swim stress. First hindpaw response (HPR) latencies were recorded. Data are expressed as mean \pm SEM. Data were subjected to two-way ANOVA with stress and genotype as between-subject variables. One symbol, $p<0.05$; two symbols, $p<0.01$; three symbols, $p<0.001$; black stars, effect of stress (Bonferroni post hoc test). ated: hindpaw licking and hindpaw shaking. The response occurring first was taken into account. Three time points $(1,2$, and $5 \mathrm{~min}$ rest following the swim stress) were first tested on WT Bl6 females to assess whether the latency to display this first hindpaw response would be increased by stress (Figure 5b). There was a main effect of stress $(\mathrm{F}(3,30)=3.6 ; p=0.02)$ that ended up to be significant 2 min poststress. Mutant females were therefore tested at this time point (Figure 5c). Two-way ANOVA detected a stress effect $(\mathrm{F}(1,54)=36.0 ; p<0.001)$ and no genotype effect $(\mathrm{F}(3,54)=1.5 ; p>0.05)$ and no interaction of genotype with stress $(\mathrm{F}(3,54)=0.7 ; p>0.05)$. Subsequent post hoc analysis indicated that stress significantly increased the latency of first hindpaw response in all genotypes. First hindpaw response was also evaluated in WT 50:50 females, but stress did not affect the latency in this genetic background (no stress: $43.4 \pm 5.0 \mathrm{~s} ; 1 \mathrm{~min}$ poststress: $49.8 \pm 4.6 \mathrm{~s} ; 2 \mathrm{~min}$ poststress: $43.5 \pm 1.9 \mathrm{~s} ; 5 \mathrm{~min}$ poststress: $42.6 \pm 3.2 \mathrm{~s} ; \mathrm{F}(3,28)=0.7 ; p>0.05)$. Therefore, the effect of triple opioid receptor deletion on this parameter was not assessed in MKD-I- mice.

\section{Stress-Induced ACTH Release}

In wild-type animals, swim stress triggered the release of ACTH from the pituitary gland, as assessed by an increase of the plasma level of ACTH. Neither the deletion of individual $\mathrm{mu}$, delta, or kappa opioid receptor nor the triple mutation affected this stress-induced elevation in plasma ACTH (Figure 6). In all groups, three-way ANOVAs revealed a significant effect of stress (WT/MKD-/-: $\mathrm{F}(1,56)=91.0 ; \quad p<0.001 ; \quad \mathrm{WT} / \mathrm{MOR}-/-: \quad \mathrm{F}(1,63)=94.0$; $p<0.001 ; \mathrm{WT} / \mathrm{DOR}-/-: \mathrm{F}(1,69)=84.9 ; \quad p<0.001 ; \mathrm{WT} /$ KOR $-/-: \quad \mathrm{F}(1,62)=161.7 ; p<0.001)$ and no effect of genotype (WT/MKD-/-, WT/MOR-/-, WT/DOR-/and $\mathrm{WT} / \mathrm{KOR}-/-: p>0.05)$. Sex effect was present in $\mathrm{WT} / \mathrm{MKD}-/-(\mathrm{F}(1,56)=13.9 ; p<0.001)$ and $\mathrm{WT} / \mathrm{KOR}-I-$ mice $(\mathrm{F}(1,62)=9.7 ; p=0.003)$ but absent in $\mathrm{WT} / \mathrm{MOR}-/-$ $(p>0.05)$ and WT/DOR $-/-$ animals $(p>0.05)$. There was no interaction of genotype with stress (WT/MKD-/-, WT/ MOR $-I-, \mathrm{WT} / \mathrm{DOR}-I-$ and $\mathrm{WT} / \mathrm{KOR}-I-: p>0.05)$ or with sex (WT/MKD-l-, WT/MOR $-/-$, WT/DOR $-/-$ and $\mathrm{WT} / \mathrm{KOR}-/-: p>0.05)$. Apart from WT/DOR-I- mice $(\mathrm{F}(1,69)=6.2 ; p=0.02)$, stress did not interact with sex (WT/MKD-l-, WT/MOR-I- and WT/KOR $-/-: p>0.05$ ). The triple interaction was not significant except in WT/ MOR-I- group (WT/MOR-I-: $\mathrm{F}(1,63)=4.7 ; p=0.03$; $\mathrm{WT} / \mathrm{MKD}-1-$, WT/DOR-/- and WT/KOR-/-: $p>0.05$ ). Post hoc analyses indicated that stress induced a robust increase in plasma ACTH in both genders of all genotypes. Sexual dimorphism was evidenced on the 50:50 genetic background, with females displaying lower pre- and poststress ACTH levels than males. There was also a gender difference in one group of WT Bl6 mice, but this disparity disappeared when all WT Bl6 groups were pooled for analysis (not shown).

\section{Stress-Induced Corticosterone Secretion}

In wild-type animals, swim stress induced an increase of corticosterone plasma level. As for ACTH, the secretion of corticosterone remained unchanged upon deletion of opioid 

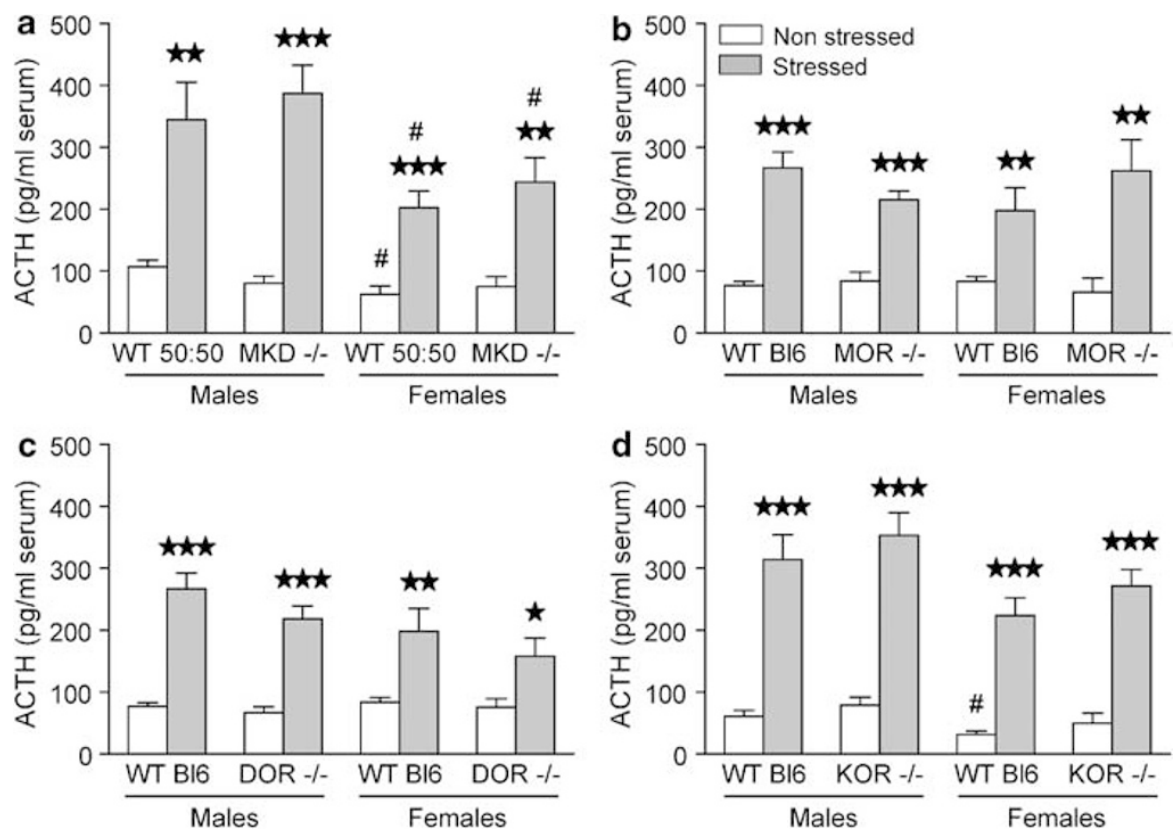

Figure 6 Effect of opioid receptor deletion on stress-induced increase in plasma ACTH level. Male and female MKD-/- (a, $n=7-9)$, MOR-/- (b, $n=6-13), \mathrm{DOR}-1-(\mathrm{c}, n=6-13)$, and KOR $-1-(\mathrm{d}, n=7-1 \mathrm{I})$ mice were compared to their wild-type counterparts (WT 50:50 and WT BI6). Mice were exposed to swim stress during $3 \mathrm{~min}$ in $32^{\circ} \mathrm{C}$ water and were killed $10 \mathrm{~min}$ after stress. Data are expressed as mean \pm SEM. Data were subjected to threeway ANOVA with stress, genotype, and sex as between-subject variables. One symbol, $p<0.05$; two symbols, $p<0.0$ l; three symbols, $p<0.00$ l; black stars, effect of stress; sharp symbols, effect of sex (Bonferroni post hoc test).
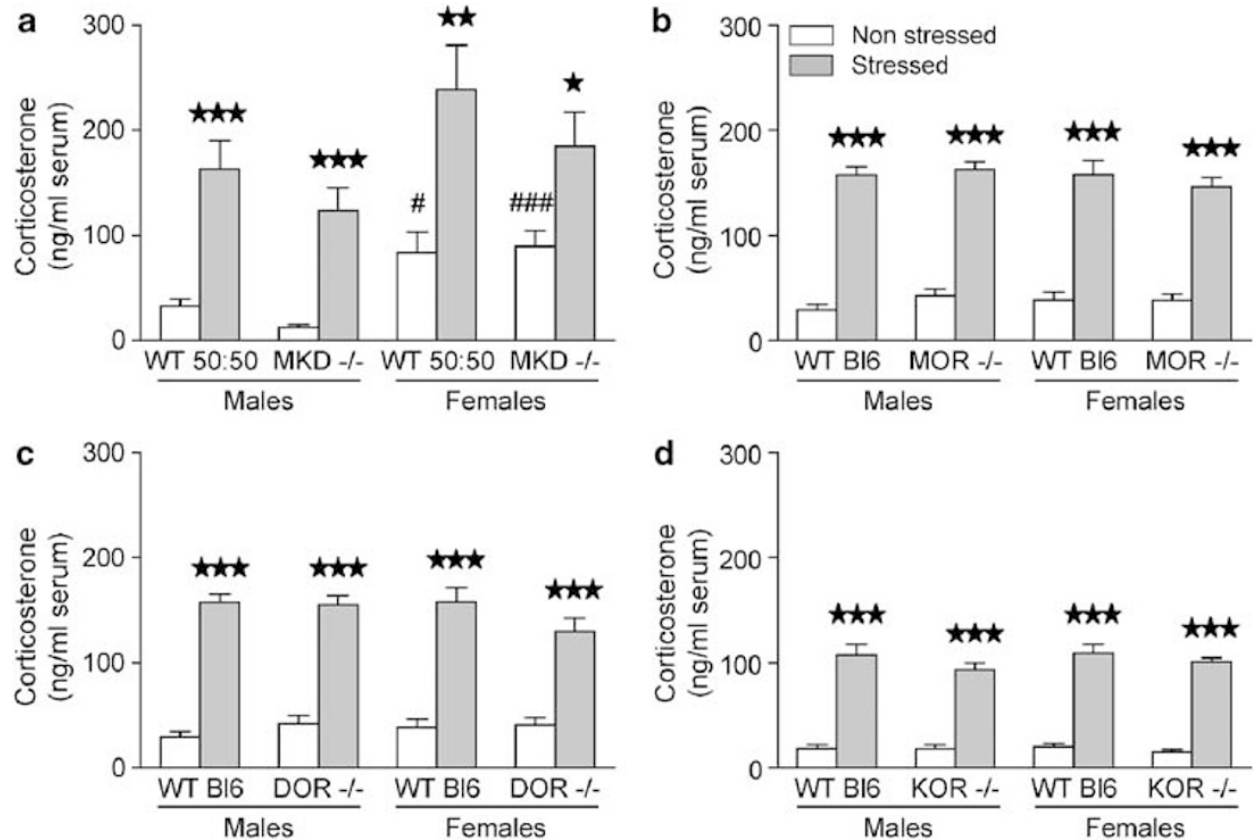

Figure 7 Effect of opioid receptor deletion on stress-induced increase in plasma corticosterone level. Male and female MKD-/- (a, n=7-9), MOR-/(b, $n=10-16)$, DOR-l- $(c, n=12-16)$, and KOR-I- $(d, n=7-10)$ mice were compared to their wild-type counterparts (WT 50:50 and WT Bl6). Mice were exposed to swim stress during $3 \mathrm{~min}$ in $32^{\circ} \mathrm{C}$ water and were killed $10 \mathrm{~min}$ after stress. Data are expressed as mean \pm SEM. Data were subjected to three-way ANOVA with stress, genotype, and sex as between-subject variables. One symbol, $p<0.05$; two symbols, $p<0.0$ l; three symbols, $p<0.00$ I; black stars, effect of stress; sharp symbols, effect of sex (Bonferroni post hoc test).

receptors (Figure 7). In all groups, the effect of stress was significant $(\mathrm{WT} / \mathrm{MKD}-/-: \mathrm{F}(1,56)=51.7 ; p<0.001$; WT/MOR $-1-: \quad \mathrm{F}(1,96)=440.4 ; \quad p<0.001 ; \quad \mathrm{WT} / \mathrm{DOR}-/-$ : $\mathrm{F}(1,102)=311.9 ; p<0.001 ; \mathrm{WT} / \mathrm{KOR}-/-: \mathrm{F}(1,63)=404.5$; $p<0.001$ ) and there was no effect of genotype (WT/ MKD $-1-$, WT/MOR-1-, WT/DOR-I- and WT/KOR-I-: $p>0.05)$. Sex effect was present only in MKD $-/-$ mice $(\mathrm{WT} / \mathrm{MKD}-/-\mathrm{F}(1,56)=15.1 ; \quad p<0.001 ; \quad \mathrm{WT} / \mathrm{MOR}-/-$, 
$\mathrm{WT} / \mathrm{DOR}-/-$ and $\mathrm{WT} / \mathrm{KOR}-/-:$ p $>0.05)$. There was no interaction between stress and genotype (WT/MKD-/-, $\mathrm{WT} / \mathrm{MOR}-/-$, WT/DOR $-/-$ and WT/KOR $-/-: p>0.05)$, between stress and sex (WT/MKD-/-, WT/MOR-/-, WT/ DOR $-I-$ and WT/KOR-I-: $p>0.05)$, between genotype and sex (WT/MKD-/-, WT/MOR-/-, WT/DOR $-/-$ and $\mathrm{WT} / \mathrm{KOR}-/-: p>0.05)$, nor between the three variables (WT/MKD-/-, WT/MOR-/-, WT/DOR-/- and WT/ KOR $-/-: p>0.05)$. Subsequent post hoc tests evidenced that stress produced a substantial rise in plasma corticosterone whatever gender or genotype was considered. Sexual dimorphism again appeared on the mixed genetic background, with females harboring higher basal corticosterone concentrations than males.

\section{DISCUSSION}

This is the first study assessing stress-induced analgesia and HPA axis activity simultaneously in all three strains of opioid receptor knockout mice, together with naloxonetreated and triple knockout mice.

We used a well-accepted procedure to induce opioidmediated stress-induced analgesia, namely a 3-min forced swim in $32{ }^{\circ} \mathrm{C}$ water (Mogil et al, 1996). Analgesia was measured in the hot plate and the tail immersion tests, two classical assays reflecting distinct modalities of thermal nociception (see Tjolsen and Hole, 1997). The tail immersion test indicates a spinal nociceptive reflex, while the hot plate test requires neuronal circuitry of both brain and spinal cord and thus reflects an integrated behavioral response to stress (Tjolsen and Hole, 1997).

In our experimental procedure, wild-type mice bearing distinct genetic backgrounds had different pain sensitivity, as measured by the jump end point in the hot plate assay. Mice with a hybrid $129 / \mathrm{SvPas} \times \mathrm{C} 57 \mathrm{BL} / 6 \mathrm{~J}$ genetic background displayed longer jumping latencies than animals backcrossed on C57BL/6J genetic background. This strain difference was not detected with the frontpaw licking latency. A previous study similarly reported strain differences in analgesia in the hot plate test using a given behavioral end point but not another (Belknap et al, 1990). C57BL/6J mice are generally depicted as highly sensitive to thermal stimulus, both in the hot plate (Elmer et al, 1998) and in the tail immersion assays (Mogil and Wilson, 1997; Mogil et al, 1999). On the contrary, 129 mice are classified as normal or low responders to thermal stimulus, although distinct 129 substrains can markedly differ from each other (Simpson et al, 1997; Threadgill et al, 1997). When compared in the same study, 129 mice were in any case less sensitive than C57BL/6J mice (Mogil and Wilson, 1997; Mogil et al, 1999). Our observation that animals carrying half 129/SvPas and half C57BL/6J genetic contents are more resistant to thermal pain than $100 \% \mathrm{C} 57 \mathrm{BL} / 6 \mathrm{~J}$ mice is therefore consistent with published literature.

Further examining our wild-type animals, we detected sexual dimorphism both in the jumping and the frontpaw licking latencies in the hot plate test. In our conditions, females displayed consistently more analgesia than males, although this gender difference reached significance only on the C57BL/6J genetic background. Females had not only higher baseline values (jumping only) but also markedly longer poststress latencies (jumping and frontpaw licking). While most studies reporting sexual dimorphism in rodents related that females were more sensitive to pain than males, there are considerable variations between animal species/ strains and between nociception assays (for reviews, see Mogil et al, 2000; Craft, 2003). Across 40 different mouse strains tested for baseline nociception in the tail immersion test, the computational analysis performed by Chesler et al (2002) evidenced that sex could account for no more than $0.4 \%$ of the total variance. Sex thus does not seem to influence thermal nociception in a constant direction in distinct mouse strains. Concerning the influence of sex on stress-induced analgesia, no previous study specifically addressed this issue in our model, namely a warm water forced swim stress. Possible mechanisms underlying sexual dimorphism in our paradigm involve the influence of gonadal hormones on nociception circuitry. In particular, it was shown that estrogens could modulate opioid peptide and receptor expression, possibly enhancing endogenous pain inhibitory circuits in females (see Craft et al, 2004).

The stress procedure that we applied was reported to predominantly recruit the endogenous opioid system to produce antinociception (Mogil et al, 1996). In accordance, we found that stress-induced analgesia was totally (C57BL/ $6 \mathrm{~J}$ males) or partially (other groups) reversed by naloxone. In addition, the tendency of naloxone to decrease basal latencies in nonstressed animals indicates that an endogenous opioidergic tone produces subtle analgesia, as previously described (Berntson and Walker, 1977; Coderre and Rollman, 1983).

Interestingly, the genetic inactivation of all three opioid receptors (in $\mathrm{MKD}-/-$ mice) produced similar data to pharmacological blockade (by naloxone). First, the decreased stress-induced analgesia in $\mathrm{MKD}-/-$ mice again demonstrates that, in our model, analgesia is mainly mediated by the opioid system. We also observed a significant decrease in baseline, reflecting the inhibitory opioidergic tone on pain perception. This finding is in accordance with data previously reported with these mice (Martin et al, 2003; Scherrer et al, 2004).

Regarding the single knockout animals, we obtained divergent results depending on the nociceptive end point considered. The jump parameter in the hot plate test indicated that stress-induced analgesia was decreased in MOR $-I-$ and DOR $-I-$ females, and remained unchanged upon inactivation of any individual opioid receptor in males. Conversely, mutant females did not differ from wildtype mice regarding frontpaw licking and hindpaw licking/ shaking latencies in the hot plate test and tail-flick latency in the tail immersion test. This discrepancy most probably arises from the distinct pain modalities reflected by these various end points, as previously observed in other studies (Fasmer et al, 1986; Hill et al, 1987; Perissin et al, 2000; Harasawa et al, 2003). Tail-flick in the tail immersion test is a pure reflex response, maintained following spinal transection (Irwin et al, 1951). Front- or hindpaw licking/ shaking consists in both a spinal reflex (paw withdrawal from the heated surface) and a supraspinally coordinated behavior (licking or shaking per se). Frontpaw licking is generally considered as a misleading end point since it belongs to the normal mouse grooming behavior (see Wilson and Mogil, 2001). Hindpaw licking was also shown 
to be potentially confounding since nonanalgesic drugs could alter this response (Carter, 1991). Jumping usually occurs after a prolonged exposure to heat and reflects pain tolerance threshold, thereby encompassing an affective component of pain (O'Neill et al, 1983; Espejo and Mir, 1993). As a conclusion, our data suggest that mu and delta receptors would mediate the most integrated level of stressinduced analgesia in females.

Previous studies using selective antagonists to reverse opioid stress-induced analgesia mostly reported a role for the delta receptor. However, other studies also indicated the involvement of kappa and mu receptors (see Yamada and Nabeshima, 1995 and references therein). Altogether, it appears that the recruitment of distinct opioid receptor types is highly dependent on the experimental conditions (mouse strain, age, gender, stressor type, analgesia assay), therefore highlighting that our findings are restricted to our particular protocol. As compared to other studies conducted in knockout animals, our data in females correlate well with the reduction of stress-induced analgesia in $\beta$ endorphin-deficient mice (Rubinstein et al, 1996). On the other hand, lack of change in kappa receptor knockout mice differs from the abolition of stress-induced analgesia in prodynorphin knockout mice (McLaughlin et al, 2003). This may be due to the use of distinct stress intensity (repeated vs single swim). Alternatively, prodynorphin and kappa opioid receptor knockout mice are not strictly equivalent animal models. Prodynorphin gene encodes a number of opioid peptides (dynorphins A and B, leumorphin, $\alpha$ - and $\beta$-neoendorphins) that bind with low selectivity to $\mathrm{mu}$, delta, and kappa opioid receptors (see Akil et al, 1997). In addition, dynorphin $\mathrm{A}$ and leumorphin were shown to act at non-opioid targets (see Lai et al, 2001; Lee et al, 2005). Finally, our data obtained with the males are consistent with a previous paper reporting unchanged stress-induced analgesia in mu receptor knockout mice $5 \mathrm{~min}$ after swim stress (LaBuda et al, 2000).

The lack of phenotype of single knockout males contrasts with the strong phenotype observed in triple knockout males. It seems unlikely that the genetic background is responsible for this discrepancy, since naloxone was as effective in WT Bl6 as in WT 50:50 to inhibit stress-induced analgesia. Most probably, the addition of subtle MOR-, DOR-, and/or KOR-mediated effects contributed to the highly significant change detected in triple knockout mice. Interestingly, this additive phenomenon was previously shown for the endogenous antinociceptive tones using the same animals (Martin et al, 2003). The collateral inhibition demonstrated between opioid and non-opioid stressinduced analgesia could also provide an explanation for the poor phenotype in single knockout mutants (Hopkins et al, 1998). The original data suggesting the existence of a collateral inhibition was that naloxazone, an opioid antagonist, potentiated non-opioid stress-induced analgesia (Kirchgessner et al, 1982). In our model, stress-induced analgesia is not entirely mediated by the opioid system since some analgesia remains following naloxone injection or genetic inactivation of the three opioid receptors. It could therefore be that the deletion of a given opioid receptor in single mutants facilitates the non-opioid component of stress-induced analgesia and thus masks the reduction of the opioid component.
At the hormonal level, we observed two kinds of sexual dimorphism in the hybrid 129/SvPas $\times$ C57BL/6J genetic background (WT 50:50). First, basal corticosterone concentrations were higher in females than in males, despite similar or lower basal ACTH levels. Second, stress-induced ACTH values were lower in females than in males, despite comparable or higher poststress corticosterone levels. The former feature is well documented, at least in the rat, and suggests a higher responsiveness of adrenal cortex to ACTH in females (see Atkinson and Waddell, 1997 and references therein; Spinedi et al, 1997). Supporting this hypothesis, TLR2-/- mutant mice that bear an impaired adrenal gland display higher ACTH but decreased corticosterone basal levels (Bornstein et al, 2004). The latter aspect can also be explained by this mechanism, where less ACTH is required to achieve a given corticosterone response. Interestingly, a genetic model of high adrenal responsiveness (Dax-1 $1^{-/ Y}$ mice) was developed and displayed decreased ACTH but unchanged corticosterone levels following restraint stress (Babu et al, 2002), reminiscent of the phenotype of WT 50:50 females compared to males following our swim stress paradigm. Dax $-1^{-/ Y}$ mice also have reduced basal ACTH concentrations, similar to WT 50:50 females (Babu et al, 2002). Noticeably, an identical sexual dimorphism in basal and poststress ACTH and corticosterone levels was previously observed (Timpl et al, 1998).

Basal ACTH and corticosterone levels were unchanged in all strains of knockout mice. These data indicate that, under our conditions, the endogenous opioid system does not tonically modulate the basal HPA axis activity, or that compensatory changes may have developed in the knockout animals. A two-fold increase in basal plasma ACTH and corticosterone levels was previously evidenced in another strain of mu receptor knockout mice (Roy et al, 2001). This divergence with our data could arise from a difference in genetic background between the two strains (C57BL/6 vs $\mathrm{BALB} / \mathrm{c} \times \mathrm{C} 57 \mathrm{BL} / 6)$. It should however be noted that the same animals were found to have corticosterone levels equal to those of wild-type mice in a later study (Wang et al, 2002).

Our swim stress procedure induced a prominent increase in both plasma ACTH and corticosterone levels in all mice. We found no difference between stress-induced levels of wild-type and knockout mice. We also tested naloxone's effect on hormonal stress response. However, the saline control injection per se produced a strong increase of ACTH and corticosterone plasma concentrations (up to threefold), which was comparable to the increase induced by the swim stress procedure in noninjected mice (three- to fivefold). Under those conditions, the swim stress effect was mild and no significant effect of naloxone treatment as compared to saline injection was detected (data not shown).

Previous studies testing the effect of opioid antagonists on basal and stress-induced ACTH and corticosterone levels brought controversial results, reporting either decreased, increased, or unchanged levels (Pfeiffer and Herz, 1984; Buckingham and Cooper, 1986; Cover and Buckingham, 1989; Odio and Brodish, 1990). In the study by Wang et al (2002), mu receptor knockout mice displayed reduced elevation in plasma corticosterone following chronic restraint stress. The discrepancy with our data may arise from the use of distinct stressors (chronic restraint $v s$ forced 
swim) that may differentially involve mu opioid receptors in corticosterone secretion. On the other hand, our results are in agreement with data obtained with opioid peptide knockout animals. Both basal and stress-induced corticosterone levels were unchanged in $\beta$-endorphin-deficient mice (Rubinstein et al, 1996) and both basal and stress-induced ACTH levels were unaffected in preproenkephalin knockout mice (Bilkei-Gorzo et al, 2004).

Our data suggest that the endogenous opioid system contributes to the most integrated component of stressinduced analgesia, but not to HPA axis activation, in our strains of mice and using our stress protocol. Previous studies have already evidenced a dissociation between mechanisms mediating antinociceptive and hormonal responses to stress. Stressors inducing maximal ACTH and corticosterone release may trigger minimal analgesia (Kelly, 1982). Hart et al (1985) reported that the degree of antinociception was not related to corticosterone levels measured $11 \mathrm{~min}$ after a 3 -min forced swim. In another paper, analgesia induced by a 3-min swim in $20^{\circ} \mathrm{C}$ water was antagonized by naltrindole whereas neither naltrindole nor naloxone affected plasma corticosterone at the time of peak antinociception (Kitchen and Pinker, 1990). The differential effect of opioid receptor deletion on analgesic and hormonal responses to stress may indicate that our stress procedure induced an 'opioid-neural' rather than an 'opioid neurohormonal' form of stress-induced analgesia, following the classification proposed by Watkins and Mayer (1982). In the future, it will be of interest to confirm this categorization by determining whether analgesia is preserved following alteration of HPA axis activity.

The dissociation of analgesic and endocrine response to mild stress is consistent with the anatomical dissociation between brain regions mediating pain modulation (mainly periaqueductal gray matter and rostral ventromedial medulla) (Fields, 1993) and the HPA axis. However, some brain structures commonly control descending pain inhibitory pathway and the HPA axis (Herman and Cullinan, 1997). For instance, the central nucleus of the amygdala sends projections to both periaqueductal gray matter (Rizvi et al, 1991) and paraventricular nucleus of the hypothalamus (Gray et al, 1989), and lesion of this nucleus reduces stress-induced analgesia (Werka and Marek, 1990) as well as corticosterone release (Van de Kar et al, 1991). From our data, it seems that opioid receptors expressed in central nucleus of the amygdala either are not generally involved in the responses to stress observed in our study or do contribute to the nociceptive response only by a mechanism that remains to be explored.

In conclusion, our parallel analysis of single and triple opioid receptor knockout mice exposed to an acute stress highlight that stress-induced analgesia can be mediated by endogenous opioids independently from HPA axis activity. Future studies will examine the involvement of opioid receptors in behavioral models of chronic stress.

\section{ACKNOWLEDGEMENTS}

We wish to thank Jean-François Poirier, Nathalie Schallon and Brigitte Pollet for excellent animal care and Alice Chow for her kind help. This work was funded by the Centre
National de la Recherche Scientifique, the Institut National de la Santé et de la Recherche Médicale, the Hôpital Universitaire de Strasbourg, the Institut UPSA de la Douleur, the Human Frontier Science Program, NIDA (NIH-NIDA \#DA 05010) and Hoechst-Marion-Roussel.

\section{REFERENCES}

Akil H, Meng F, Devine DP, Watson SJ (1997). Molecular and neuroanatomical properties of the endogenous opioid systems: implications for the treatment of opiate addiction. Semin Neurosci 9: 70-83.

Amit Z, Galina ZH (1988). Stress induced analgesia plays an adaptive role in the organization of behavioral responding. Brain Res Bull 21: 955-958.

Atkinson HC, Waddell BJ (1997). Circadian variation in basal plasma corticosterone and adrenocorticotropin in the rat: sexual dimorphism and changes across the estrous cycle. Endocrinology 138: $3842-3848$.

Babu PS, Bavers DL, Beuschlein F, Shah S, Jeffs B, Jameson JL et al (2002). Interaction between Dax-1 and steroidogenic factor-1 in vivo: increased adrenal responsiveness to ACTH in the absence of Dax-1. Endocrinology 143: 665-673.

Belknap JK, Lame M, Danielson PW (1990). Inbred strain differences in morphine-induced analgesia with the hot plate assay: a reassessment. Behav Genet 20: 333-338.

Berntson GG, Walker JM (1977). Effect of opiate receptor blockade on pain sensitivity in the rat. Brain Res Bull 2: 157-159.

Bilkei-Gorzo A, Racz I, Michel K, Zimmer A, Klingmuller D (2004). Behavioral phenotype of pre-proenkephalin-deficient mice on diverse congenic backgrounds. Psychopharmacology 176: 343-352.

Bodnar RJ (1990). Effects of opioid peptides on peripheral stimulation and 'stress'-induced analgesia in animals. Crit Rev Neurobiol 6: 39-49.

Bodnar RJ, Kelly DD, Brutus M, Glusman M (1980). Stress-induced analgesia: neural and hormonal determinants. Neurosci Biobehav Rev 4: 87-100.

Bodnar RJ, Klein GE (2004). Endogenous opiates and behavior: 2003. Peptides 25: 2205-2256.

Bornstein SR, Zacharowski P, Schumann RR, Barthel A, Tran N, Papewalis C et al (2004). Impaired adrenal stress response in Toll-like receptor 2-deficient mice. Proc Natl Acad Sci USA 101: 16695-16700.

Buckingham JC, Cooper TA (1986). Effects of naloxone on hypothalamo-pituitary-adrenocortical activity in the rat. Neuroendocrinology 42: 421-426.

Cannon WB (1939). The Wisdom of the Body. Norton: New York. Carrasco GA, Van de Kar LD (2003). Neuroendocrine pharmacology of stress. Eur J Pharmacol 463: 235-272.

Carter RB (1991). Differentiating analgesic and non-analgesic drug activities on rat hot plate: effect of behavioral endpoint. Pain 47: 211-220.

Chesler EJ, Wilson SG, Lariviere WR, Rodriguez-Zas SL, Mogil JS (2002). Identification and ranking of genetic and laboratory environment factors influencing a behavioral trait, thermal nociception, via computational analysis of a large data archive. Neurosci Biobehav Rev 26: 907-923.

Coderre TJ, Rollman GB (1983). Naloxone hyperalgesia and stressinduced analgesia in rats. Life Sci 32: 2139-2146.

Cover PO, Buckingham JC (1989). Effects of selective opioidreceptor blockade on the hypothalamo-pituitary-adrenocortical responses to surgical trauma in the rat. J Endocrinol 121: 213-220.

Craft RM (2003). Sex differences in drug- and non-drug-induced analgesia. Life Sci 72: 2675-2688. 
Craft RM, Mogil JS, Aloisi AM (2004). Sex differences in pain and analgesia: the role of gonadal hormones. Eur J Pain 8: 397-411.

Drolet G, Dumont EC, Gosselin I, Kinkead R, Laforest S, Trottier JF (2001). Role of endogenous opioid system in the regulation of the stress response. Prog Neuropsychopharmacol Biol Psychiatry 25: 729-741.

Elmer GI, Pieper JO, Negus SS, Woods JH (1998). Genetic variance in nociception and its relationship to the potency of morphineinduced analgesia in thermal and chemical tests. Pain 75: 129-140.

Espejo EF, Mir D (1993). Structure of the rat's behaviour in the hot plate test. Behav Brain Res 56: 171-176.

Fasmer OB, Berge OG, Post C, Hole K (1986). Effects of the putative 5-HT1A receptor agonist 8-OH-2-(di-n-propylamino)tetralin on nociceptive sensitivity in mice. Pharmacol Biochem Behav 25: 883-888.

Fields HL (1993). Brainstem mechanisms of pain modulation: anatomy and physiology. In: Herz A (ed). Handbook of Experimental Pharmacology: Opioids II. Springer-Verlag: Berlin. pp 3-15.

Filliol D, Ghozland S, Chluba J, Martin M, Matthes HW, Simonin F et al (2000). Mice deficient for delta- and mu-opioid receptors exhibit opposing alterations of emotional responses. Nat Genet 25: $195-200$.

Goeders NE (2003). The impact of stress on addiction. Eur Neuropsychopharmacol 13: 435-441.

Goldstein DS (2003). Catecholamines and stress. Endocr Regul 37: 69-80.

Gray TS, Carney ME, Magnuson DJ (1989). Direct projections from the central amygdaloid nucleus to the hypothalamic paraventricular nucleus: possible role in stress-induced adrenocorticotropin release. Neuroendocrinology 50: 433-446.

Harasawa I, Honda K, Tanoue A, Shinoura H, Ishida Y, Okamura $\mathrm{H}$ et al (2003). Responses to noxious stimuli in mice lacking alpha(1d)-adrenergic receptors. Neuroreport 14: 1857-1860.

Hart SL, Slusarczyk H, Smith TW (1985). The effects of selective opioid delta-receptor antagonists on stress-induced antinocoception and plasma corticosterone levels in mice. Neuropeptides 5: 303-306.

Herman JP, Cullinan WE (1997). Neurocircuitry of stress: central control of the hypothalamo-pituitary-adrenocortical axis. Trends Neurosci 20: 78-84.

Hill RG, Hughes J, Pittaway KM (1987). Antinociceptive action of cholecystokinin octapeptide (CCK 8) and related peptides in rats and mice: effects of naloxone and peptidase inhibitors. Neuropharmacology 26: 289-300.

Hohmann AG, Suplita RL, Bolton NM, Neely MH, Fegley D, Mangieri $\mathrm{R}$ et al (2005). An endocannabinoid mechanism for stress-induced analgesia. Nature 435: 1108-1112.

Hopkins E, Spinella M, Pavlovic ZW, Bodnar RJ (1998). Alterations in swim stress-induced analgesia and hypothermia following serotonergic or NMDA antagonists in the rostral ventromedial medulla of rats. Physiol Behav 64: 219-225.

Hough LB, Glick SD, Su K (1985). A role for histamine and histamine H2-receptors in non-opiate footshock-induced analgesia. Life Sci 36: 859-866.

Irwin S, Houde RW, Bennett DR, Hendershot LC, Seevers MH (1951). The effects of morphine methadone and meperidine on some reflex responses of spinal animals to nociceptive stimulation. J Pharmacol Exp Ther 101: 132-143.

Kelly DD (1982). The role of endorphins in stress-induced analgesia. Ann NY Acad Sci 398: 260-271.

Kieffer BL, Gavériaux-Ruff C (2002). Exploring the opioid system by gene knockout. Prog Neurobiol 66: 285-306.

Kirchgessner AL, Bodnar RJ, Pasternak GW (1982). Naloxazone and pain-inhibitory systems: evidence for a collateral inhibition model. Pharmacol Biochem Behav 17: 1175-1179.
Kitchen I, Pinker SR (1990). Antagonism of swim-stress-induced antinociception by the delta-opioid receptor antagonist naltrindole in adult and young rats. Br J Pharmacol 100: 685-688.

Konig M, Zimmer AM, Steiner H, Holmes PV, Crawley JN, Brownstein MJ et al (1996). Pain responses, anxiety and aggression in mice deficient in pre-proenkephalin. Nature 383: 535-538.

Kreek MJ, Koob GF (1998). Drug dependence: stress and dysregulation of brain reward pathways. Drug Alcohol Depend 51: 23-47.

LaBuda CJ, Sora I, Uhl GR, Fuchs PN (2000). Stress-induced analgesia in mu-opioid receptor knockout mice reveals normal function of the delta-opioid receptor system. Brain Res 869: 1-5.

Lai J, Ossipov MH, Vanderah TW, Malan Jr TP, Porreca F (2001). Neuropathic pain: the paradox of dynorphin. Mol Interv 1: 160-167.

Lee BD, Kim S, Hur EM, Park YS, Kim YH, Lee TG et al (2005). Leumorphin has an anti-apoptotic effect by activating epidermal growth factor receptor kinase in rat pheochromocytoma PC12 cells. J Neurochem (in press).

Lewis JW, Cannon JT, Liebeskind JC (1980). Opioid and nonopioid mechanisms of stress analgesia. Science 208: 623-625.

Marek P, Mogil JS, Sternberg WF, Panocka I, Liebeskind JC (1992). $\mathrm{N}$-methyl-D-aspartic acid (NMDA) receptor antagonist MK-801 blocks non-opioid stress-induced analgesia. II. Comparison across three swim-stress paradigms in selectively bred mice. Brain Res 578: 197-203.

Martin M, Matifas A, Maldonado R, Kieffer BL (2003). Acute antinociceptive responses in single and combinatorial opioid receptor knockout mice: dictinct mu, delta and kappa tones. Eur J Neurosci 17: 1-8.

Matthes HWD, Maldonado R, Simonin F, Valverde O, Slowe S, Kitchen I et al (1996). Loss of morphine-induced analgesia, reward effect and withdrawal symptoms in mice lacking the $\mu$-opioid receptor gene. Nature 383: 819-823.

McLaughlin JP, Marton-Popovici M, Chavkin C (2003). Kappa opioid receptor antagonism and prodynorphin gene disruption block stress-induced behavioral responses. J Neurosci 23: 5674-5683.

Menendez L, Andres-Trelles F, Hidalgo A, Baamonde A (1993). Involvement of spinal $\kappa$-opioid receptors in a type of footshock induced analgesia in mice. Brain Res 611: 264-271.

Miller DB, O'Callaghan JP (2002). Neuroendocrine aspects of the response to stress. Metabolism 51: 5-10.

Mogil JS, Belknap JK (1997). Sex and genotype determine the selective activation of neurochemically-distinct mechanisms of swim stress-induced analgesia. Pharmacol Biochem Behav 56: 61-66.

Mogil JS, Chesler EJ, Wilson SG, Juraska JM, Sternberg WF (2000). Sex differences in thermal nociception and morphine antinociception in rodents depend on genotype. Neurosci Biobehav Rev 24: $375-389$.

Mogil JS, Sternberg WF, Balian H, Liebeskind JC, Sadowski B (1996). Opioid and nonopioid swim stress-induced analgesia: a parametric analysis in mice. Physiol Behav 59: 123-132.

Mogil JS, Wilson SG (1997). Nociceptive and morphine antinociceptive sensitivity of 129 and C57BL/6 inbred mouse strains: implications for transgenic knock-out studies. Eur J Pain 1: 293-297.

Mogil JS, Wilson SG, Bon K, Lee SE, Chung K, Raber P et al (1999). Heritability of nociception I: responses of 11 inbred mouse strains on 12 measures of nociception. Pain 80: 67-82.

Odio M, Brodish A (1990). Central but not peripheral opiate receptor blockade prolonged pituitary-adrenal responses to stress. Pharmacol Biochem Behav 35: 963-969.

O'Neill KA, Courtney C, Rankin R, Weissman A (1983). An automated, high-capacity method for measuring jumping latencies on a hot-plate. J Pharmacol Methods 10: 13-18. 
Perissin L, Facchin P, Porro CA (2000). Diurnal variations in tonic pain reactions in mice. Life Sci 67: 1477-1488.

Pfeiffer A, Herz A (1984). Endocrine actions of opioids. Horm Metab Res 16: 386-397.

Przewlocki R (1993). Opioid systems and stress. In: Herz A (ed). Handbook of Experimental Pharmacology: Opioids II. SpringerVerlag: Berlin. pp 293-324.

Rizvi TA, Ennis M, Behbehani MM, Shipley MT (1991). Connections between the central nucleus of the amygdala and the midbrain periaqueductal gray: topography and reciprocity. J Comp Neurol 303: 121-131.

Robertson JA, Hough LB, Bodnar RJ (1988). Potentiation of opioid and nonopioid forms of swim analgesia by cimetidine. Pharmacol Biochem Behav 31: 107-112.

Rodgers RJ, Randall JI (1988). Environmentally induced analgesia: situational factors, mechanisms and significance. In: Rodgers RJ, Cooper SJ (eds). Endorphins, Opiates and Behavioural Processes. John Wiley \& Sons: New York. pp 107-142.

Roy S, Wang JH, Balasubramanian S, Sumandeep S, Charboneau R, Barke $\mathrm{R}$ et al (2001). Role of hypothalamic-pituitary axis in morphine-induced alteration in thymic cell distribution using mu-opioid receptor knockout mice. J Neuroimmunol 116: 147-155.

Rubinstein M, Mogil JS, Japòn M, Chan EC, Allen RG, Low MJ (1996). Absence of opioid stress-induced analgesia in mice lacking $\beta$-endorphin by site-directed mutagenesis. Proc Natl Acad Sci USA 93: 3995-4000.

Scherrer G, Befort K, Contet C, Becker J, Matifas A, Kieffer BL (2004). The delta agonists DPDPE and deltorphin II recruit predominantly mu receptors to produce thermal analgesia: a parallel study of mu, delta and combinatorial opioid receptor knockout mice. Eur J Neurosci 19: 2239-2248.

Simonin F, Valverde O, Smadja S, Slowe S, Kitchen I, Dierich A et al (1998). Disruption of the $\kappa$-opioid receptor gene in mice enhances sensitivity to chemical visceral pain, impairs pharmacological actions of the selective $\kappa$-agonist U-50, $488 \mathrm{H}$ and attenuates morphine withdrawal. EMBO J 17: 886-897.

Simpson EM, Linder CC, Sargent EE, Davisson MT, Mobraaten LE, Sharp JJ (1997). Genetic variation among 129 substrains and its importance for targeted mutagenesis in mice. Nat Genet 16: 19-27.

Slugg RM, Hayward MD, Ronnekleiv OK, Low MJ, Kelly MJ (2000). Effect of the mu-opioid agonist DAMGO on medial basal hypothalamic neurons in beta-endorphin knockout mice. Neuroendocrinology 72: 208-217.

Snow AE, Tucker SM, Dewey WL (1982). The role of neurotransmitters in stress-induced antinociception (SIA). Pharmacol Biochem Behav 16: 47-50.

Spinedi E, Chisari A, Pralong F, Gaillard RC (1997). Sexual dimorphism in the mouse hypothalamic-pituitary-adrenal axis function after endotoxin and insulin stresses during development. Neuroimmunomodulation 4: 77-83.

Tafet GE, Bernardini R (2003). Psychoneuroendocrinological links between chronic stress and depression. Prog Neuropsychopharmacol Biol Psychiatry 27: 893-903.

Terman GW, Morgan MJ, Liebeskind JC (1986). Opioid and non-opioid stress analgesia from cold water swim: importance of stress severity. Brain Res 372: 167-171.

Threadgill DW, Yee D, Matin A, Nadeau JH, Magnuson T (1997). Genealogy of the 129 inbred strains: $129 / \mathrm{SvJ}$ is a contaminated inbred strain. Mamm Genome 8: 390-393.

Timpl P, Spanagel R, Sillaber I, Kresse A, Reul JMHM, Stalla GK et al (1998). Impaired stress response and reduced anxiety in mice lacking a functional corticotropin-releasing hormone receptor 1. Nat Genet 19: 162-166.

Tjolsen A, Hole K (1997). Animal models of analgesia. In: Dickenson A, Besson J-M (eds). The Pharmacology of Pain. Springer-Verlag: Berlin. pp 1-20.

Tsigos C, Chrousos GP (2002). Hypothalamic-pituitary-adrenal axis, neuroendocrine factors and stress. J Psychosom Res 53: 865-871.

Vaanholt LM, Turek FW, Meerlo P (2003). Beta-endorphin modulates the acute response to a social conflict in male mice but does not play a role in stress-induced changes in sleep. Brain Res 978: 169-176.

Van de Kar LD, Piechowski RA, Rittenhouse PA, Gray TS (1991). Amygdaloid lesions: differential effect on conditioned stress and immobilization-induced increases in corticosterone and renin secretion. Neuroendocrinology 54: 89-95.

Wang J, Charboneau R, Barke RA, Loh HH, Roy S (2002). $\mathrm{Mu}$-opioid receptor mediates chronic restraint stress-induced lymphocyte apoptosis. J Immunol 169: 3630-3636.

Watkins LR, Mayer DJ (1982). Organization of endogenous opiate and nonopiate pain control systems. Science 216: $1185-1192$.

Werka T, Marek P (1990). Post-stress analgesia after lesions to the central nucleus of the amygdala in rats. Acta Neurobiol Exp (Wars) 50: 13-22.

Wilson SG, Mogil JS (2001). Measuring pain in the (knockout) mouse: big challenges in a small mammal. Behav Brain Res 125: 65-73.

Yamada K, Nabeshima T (1995). Stress-induced responses and multiple opioid systems in the brain. Behav Brain Res 67: 133-145.

Yamauchi N, Shibasaki T, Wakabayashi I, Demura H (1997). Brain beta-endorphin and other opioids are involved in restraint stress-induced stimulation of the hypothalamic-pituitary-adrenal axis, the sympathetic nervous system, and the adrenal medulla in the rat. Brain Res 777: 140-146. 